\title{
Cold Argon Plasma as Adjuvant Tumour Therapy on Progressive Head and Neck Cancer: A Preclinical Study
}

\author{
Sybille Hasse ${ }^{1, t, *}$, Christian Seebauer ${ }^{2,+}$, Kristian Wende $^{1,3}$, Anke Schmidt ${ }^{1}$, \\ Hans-Robert Metelmann ${ }^{2}(\mathbb{B})$, Thomas von Woedtke ${ }^{1,4}(\mathbb{D}$ and Sander Bekeschus 1,3(1) \\ 1 Leibniz Institute for Plasma Science and Technology (INP), Felix-Hausdorff-Str. 2, 17489 Greifswald, \\ Germany; kristian.wende@inp-greifswald.de (K.W.); anke.schmidt@inp-greifswald.de (A.S.); \\ woedtke@inp-greifswald.de (T.v.W.); sander.bekeschus@inp-greifswald.de (S.B.) \\ 2 Department of Oral and Maxillofacial Surgery, Plastic Surgery, University Medicine Greifswald, \\ Ferdinand-Sauerbruch-Str, 17475 Greifswald, Germany; seebauerc@uni-greifswald.de (C.S.); \\ metelman@uni-greifswald.de (H.-R.M.) \\ 3 Leibniz Institute for Plasma Science and Technology (INP), ZIK Plasmatis, Felix-Hausdorff-Str. 2, \\ 17489 Greifswald, Germany \\ 4 Department of Hygiene and Environmental Medicine, University Medicine Greifswald, \\ Walther-Rathenau-Str. 49a, 17475 Greifswald, Germany \\ * Correspondence: sybille.hasse@inp-greifswald.de; Tel.: +49-3834-554-3921 \\ + Those authors contributed equally to this paper.
}

Received: 29 April 2019; Accepted: 14 May 2019; Published: 19 May 2019

\begin{abstract}
Investigating cold argon plasma (CAP) for medical applications is a rapidly growing, innovative field of research. The controllable supply of reactive oxygen and nitrogen species through CAP has the potential for utilization in tumour treatment. Maxillofacial surgery is limited if tumours grow on vital structures such as the arteria carotis. Here CAP could be considered as an option for adjuvant intraoperative tumour therapy especially in the case of squamous cell carcinoma of the head and neck. Further preclinical research is necessary to investigate the efficacy of this technology for future clinical applications in cancer treatment. Initially, a variety of in vitro assays was performed on two cell lines that served as surrogate for the squamous cell carcinoma (SCC) and healthy tissue, respectively. Cell viability, motility and the activation of apoptosis in SCC cells (HNO97) was compared with those in normal HaCaT keratinocytes. In addition, induction of apoptosis in ex vivo CAP treated human tissue biopsies of patients with tumours of the head and neck was monitored and compared to healthy control tissue of the same patient. In response to CAP treatment, normal HaCaT keratinocytes differed significantly from their malignant counterpart HNO97 cells in cell motility only whereas cell viability remained similar. Moreover, CAP treatment of tumour tissue induced more apoptotic cells than in healthy tissue that was accompanied by elevated extracellular cytochrome c levels. This study promotes a future role of CAP as an adjuvant intraoperative tumour therapy option in the treatment of head and neck cancer. Moreover, patient-derived tissue explants complement in vitro examinations in a meaningful way to reflect an antitumoral role of CAP.
\end{abstract}

Keywords: cold argon plasma; head and neck squamous cell carcinoma; apoptosis; keratinocytes; plasma medicine

\section{Introduction}

Squamous cell carcinoma (SCC) is the second most frequent type of skin cancer after basal cell carcinoma [1] and arises frequently in the head and neck area. Treatment is multifaceted, challenging and has to be performed on an individualised basis. Complexity and variability of different tumour entities demand specific cancer therapies including surgery, chemotherapy or radiotherapy. Standard 
therapy for most of the extra- and intraoral tumours is based on a radical surgery combined with stage-based neo-adjuvant and / or adjuvant chemotherapy or radiation. Yet to date, patients suffering from advanced head and neck cancer are still faced with a poor prognosis, if cancer cells are infiltrating sensitive anatomical structures such as the skull base, the ocular bulb or main arteries that cannot be resected safely (one example is given in Figure 1). To reduce chemotherapy side effects and improve clinical outcomes, additional intraoperative antitumor treatment tools are urgently needed to complement current therapies. Cold atmospheric pressure plasma (CAP) at temperatures within physiological ranges offers versatile options for biological and medical applications in general [2-5] and recently was promoted to aid in cancer therapy [6-9].

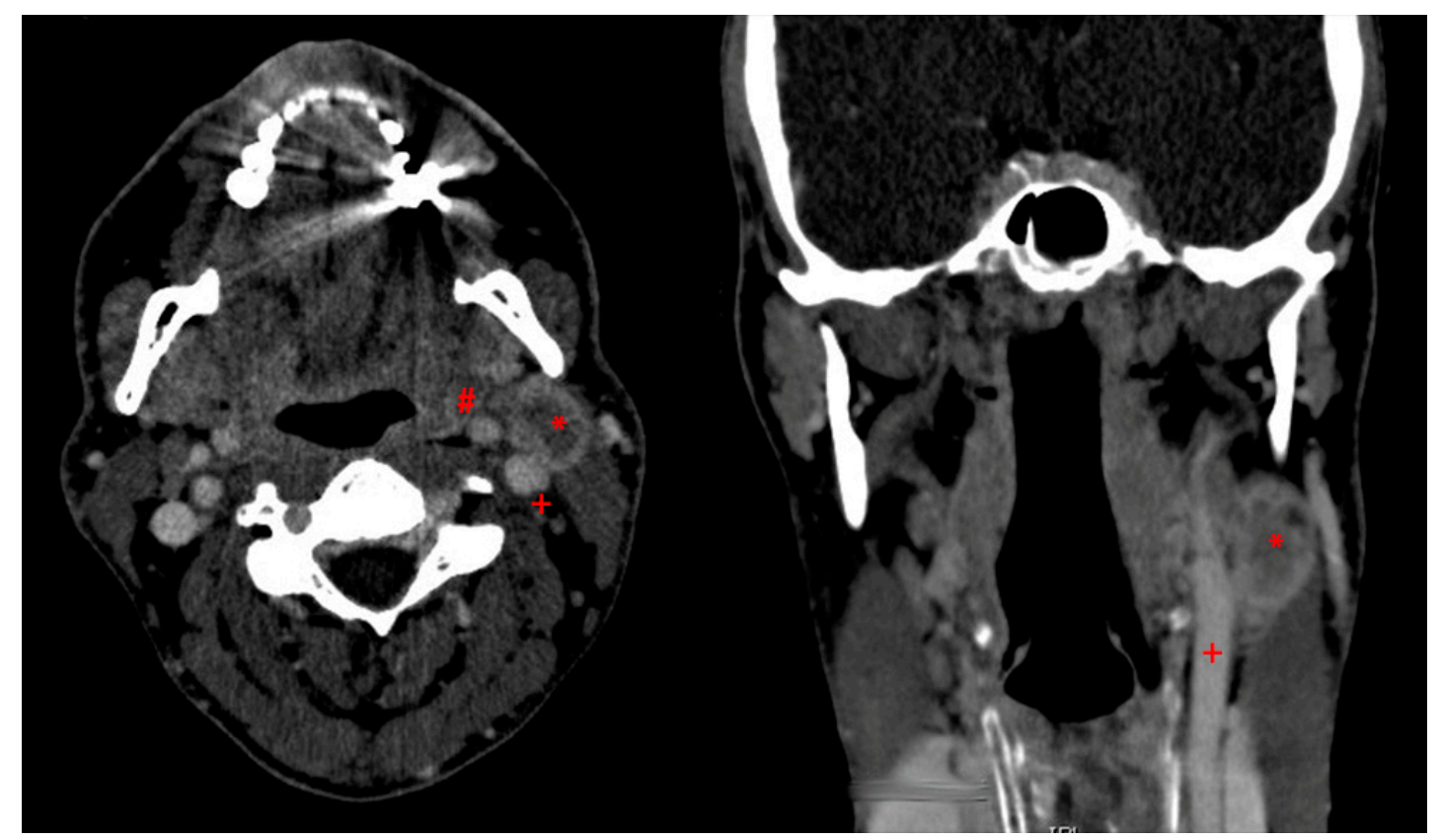

Figure 1. Axial (left) and coronal (right) cross sectional radiographic images of a lymph node metastasis ${ }^{*}$ ) of the left cervical level IIb of a 38 years old male patient suffering from an advanced squamous cell carcinoma of the oral cavity at retromolar region (UICC stadium IVa). Primary carcinoma has been surgically removed with a surrounding safety margin. Due to the metastasis' closeness to the vascular wall of the arteria carotis interna (\#) and externa (+), a surgical removal could not be performed with a safety distance. Biopsy testing for the presence of possible remaining tumour cells at the vascular wall could not be performed. So, possible remaining tumour cells can be the reason for tumour recurrence or metastasis.

Plasma is often referred to as the fourth state of matter and is considered the most reactive one. Therapeutic effects are achieved in a single treatment modality due to the combined action of ultraviolet radiation, charged particles, reactive oxygen species (ROS), reactive nitrogen species (RNS) and electrical fields $[2,10]$. First results on the compatibility and application of CAP were gained in the field of dermatology as well as in plastic and aesthetic medicine [11-17]. CAP applications can range from anti-inflammatory [18] and antimicrobial [19,20] to tissue stimulatory [21] therapeutic effects. In addition, recently Vandamme et al. and others have shown that CAP can inhibit tumour growth by ROS-mediated apoptosis [6,22,23]. Moreover, there are indications that CAP works selective for cancer cells by killing them more effectively than non-neoplastic cells [24,25]. Consequently, the concept of using CAP in the manner of intra-operative neo-adjuvant tumour therapy is to treat remaining cancer cells after conventionally tumour bulk reduction by surgery as far as possible. Hence, CAP offers the potential for new adjuvant tumour therapies [6,8].

In this study, the response of healthy and tumour cells of head and neck cancer to CAP exposure was addressed by means of cell viability, cell cycle changes and motility behaviour, including possible 
target proteins and apoptosis. In addition, excised tissue samples of head and neck squamous cell carcinoma and healthy neighbouring tissue of the oral cavity of the same patient were investigated for induction of apoptosis and secreted proteins with antitumor activity. We were able to demonstrate a significant impact of CAP against malignant cells in tissue and partially in vitro. These insights are reason for hope that CAP could be an effective tool to support radical resection of head and neck cancers.

\section{Methods}

\subsection{Cell Culture}

Non-malignant HaCaT keratinocytes and malignant HNO97 (head and neck squamous cell carcinoma of the oral cavity) were employed in this study (Cell Line Service, Eppelheim, Germany). Both cell types were maintained in Roswell Park Memorial Institute (RPMI) 1640 cell culture medium supplemented with $8 \%$ heat inactivated foetal bovine serum, $100 \mathrm{IU} / \mathrm{mL}$ penicillin, $100 \mu \mathrm{g} / \mathrm{mL}$ streptomycin and $2 \mathrm{mM}$ glutamine in a humidified atmosphere at $37^{\circ} \mathrm{C}$ and $5 \% \mathrm{CO}_{2}$ (all PAN Biotech, Aidenbach, Germany).

\subsection{Tissue Samples}

Non-malignant and malignant tissue samples were collected from 10 patients ( 6 men, 4 women; mean age 59.9 years; median age 56 years; age range 43 to 75 years) with histologically proven cancers of the maxillofacial region [9 squamous cell carcinoma of the floor of the mouth $(n=5)$, the cheek $(n=2)$, the tongue $(n=1)$, the retromolar region $(n=1)$ and one adenocarcinoma of the maxillary sinus] during their preoperative inpatient care at the clinic of maxillofacial surgery / plastic surgery at the University Medicine Greifswald. Specimen were immediately immersed in William's medium (Biochrom, Cambridge, UK) supplemented with $0.25 \mu \mathrm{g} / \mathrm{mL}$ amphotericin B, $100 \mathrm{IU} / \mathrm{mL}$ penicillin and $10 \mu \mathrm{g} / \mathrm{mL}$ streptomycin (Corning, Amsterdam, The Netherlands). Subsequently, the tissue samples were treated with CAP and kept in serum free William's E medium supplemented with $100 \mathrm{IU} / \mathrm{mL}$ penicillin/ $10 \mu \mathrm{g} / \mathrm{mL}$ streptomycin, $2 \mathrm{mM}$ glutamine, $10 \mu \mathrm{g} / \mathrm{mL}$ insulin and $10 \mathrm{ng} / \mathrm{mL}$ hydrocortisone (Sigma Aldrich, Taufkirchen, Germany) for $24 \mathrm{~h}$, as described elsewhere [21,26]. All volunteers gave their written and informed consent to participate in the laboratory study and permitted the non-invasive collection of tissue samples for additional histological examinations after radical tumour surgery.

\subsection{Plasma Source and Plasma Treatment}

The certified medical device kINPen MED ${ }^{\circledR}$ (neoplas tools, Greifswald, Germany) was used to realize plasma treatment. It consists of two electrodes, a pin type high voltage electrode inside a ceramic capillary and one grounded electrode. It generates a radiofrequency signal of about $1 \mathrm{MHz}$ and a voltage amplitude of $2-3 \mathrm{kV}$. The discharge is switched on and off at a frequency of $2.5 \mathrm{kHz}$ (50:50). Argon gas (Air Liquide, Kornwestheim, Germany) flow rate was set to 5 standard litres per minute. The plasma was generated at the tip of the pin type electrode and expanded about $1 \mathrm{~cm}$ to the surrounding air outside the capillary.

In case of monolayer cells, the culture medium was exposed to the plasma effluent for the indicated length of time and plasma-treated medium was immediately added to the adherent cells whose cell culture medium was thereby replaced. By contrast, tissue samples were directly exposed to the plasma effluent at a distance of about $8 \mathrm{~mm}$ from the capillary outlet as previously described [27]. Untreated tissue samples served as negative control. The gas temperature at working distance is $35-39^{\circ} \mathrm{C}$.

\subsection{Cell Viability}

A test for cell viability was performed with a resazurin-based assay (Alamar Blue@Assay) and was evaluated as described in detail earlier [28]. Briefly, 3500 cells were seeded per well in 96-well plates and allowed to attach overnight. Plasma-treated cell culture medium $(150 \mu \mathrm{L})$ was added to each well 
and incubated for $72 \mathrm{~h}$. Plates were washed twice with Hanks buffered saline solution prior to the addition of $100 \mu \mathrm{M}$ resazurin (Alfa Aesar, Kandel, Germany) in complete cell culture medium without phenol red. Formation of resorufin was observed at $\lambda_{\mathrm{ex}} 530 \mathrm{~nm}$ and at $\lambda_{\mathrm{em}} 590 \mathrm{~nm}$ using a microplate reader (Tecan, Männedorf, Switzerland). Cell viability was calculated as percentage of control $(100 \%)$.

To investigate apoptosis in cell culture, CellEvent caspase 3/7 detection reagent (Life Technologies, Carlsbad, CA, USA) was added to cells $6 \mathrm{~h}$ after exposure to plasma-treated medium. Cell fluorescence was acquired at $\lambda_{\mathrm{ex}} 485 \mathrm{~nm}$ and $\lambda_{\mathrm{em}} 535 \mathrm{~nm}$ using the same microplate reader.

\subsection{Cell Cycle Analyses}

One million HaCaT and HNO97 cells, respectively, were seeded into $60 \mathrm{~mm}$ cell culture dishes. CAP-treated cell culture medium was added and incubated for $24 \mathrm{~h}$. Cells were detached by incubation with trypsin/EDTA. Cells were transferred into FACS tubes, washed in PBS, fixed and permeabilised in ice-cold ethanol $(70 \% \mathrm{v} / \mathrm{v})$ overnight at $4{ }^{\circ} \mathrm{C}$. Subsequently, cells were washed, and DNA was stained with 4,6-Diamidin-2-phenylindol (Sigma, Taufkirchen, Germany) in FACS-buffer for $1 \mathrm{~h}$. DNA content analysis was carried out using flow cytometry (Gallios; Beckman-Coulter, Brea, CA, USA).

\subsection{Cell Motility Assay}

$1 \times 10^{6}$ cells in $5 \mathrm{~mL}$ of fully supplemented RPMI 1640 were seeded in $60 \mathrm{~mm}$ cell culture dishes. Just before the cell culture medium was replaced by CAP treated medium a diagonal scratch was created using a $10 \mu \mathrm{L}$ pipette tip. Dishes were placed on a heated and $\mathrm{CO}_{2}$-gassed microscope stage (Zeiss, Jena, Germany). Microscopic images were taken at $24 \mathrm{~h}$. The initial gap size was set to $0 \%$ and gap closure was calculated as percent.

\subsection{DNA Fragmentation}

As a marker for apoptosis in tissue, DNA fragmentation was detected by terminal dUTP nick-end labelling (TUNEL), employing a commercially available fluorescein kit (in situ cell death detection kit, Roche applied science, Mannheim, Germany). Positive cells were evaluated using fluorescence microscopy (Zeiss, Jena, Germany) and an open source image processing software (ImageJ, version $1.47, \mathrm{NIH}, \mathrm{USA})$.

\subsection{Cytochrome C Measurements}

Twenty-four hours after CAP treatment, supernatant of cultured tissue samples were collected and stored at $-80^{\circ} \mathrm{C}$ until they were subjected to cytochrome c ELISA, according to the manufacturer's instructions (eBioscience, Affymetrix, ViennaAustria). Concentrations were normalized to total extracellular protein content (Biorad, Heracles, CA, USA).

\subsection{Cytokine Detection}

The same supernatant medium was analysed for tumour necrosis factor $\alpha(\mathrm{TNF} \alpha)$, interferon $\gamma$ (INF $\gamma$ ), interleukin (IL) 10 and IL22 using a bead-based assay, according the manufacturer's instructions (BioLegend, San Diego, CA, USA). At least 300 beads per analyte were acquired utilizing a CytoFlex flow cytometer (Beckman-Coulter, Brea, CA, USA).

\subsection{Global Protein Expression}

Global protein expression was carried out as previously described [28]. Briefly, peptides were separated using nanoliquid chromatography (Dionex Ultimate 3000; PepMap RSLC column, $75 \mu \mathrm{m}$ ID/15 cm length, Sunnyvale, CA, USA) and eluates were ionized by electrospray ionization and analysed by high resolution mass spectrometry (positive mode, QExactive, Thermo, Waltham, MA, USA). Data processing was done using Proteome Discoverer 1.4 (Thermo). Protein candidates were selected upon their involvement in pathways of metabolisms and proliferation as well as on statistical 
criteria ( $\geq \pm 2.0$-fold expression). Data were also analysed with Ingenuity Pathway Analysis software (IPA, Qiagen, Hilden, Germany) and free web-based applications (PANTHER and Uniprot.org).

\subsection{Statistics}

Statistical analysis was performed using Prism 6 (GraphPad software, version 6.05, San Diego, CA, USA). Two-way analysis of variances (ANOVA) with Dunnett correction (comparison to untreated control for each cell type separately) was employed to statistically describe cell motility data, whereas matched one-way ANOVA with Dunnett correction was applied to caspase, cell cycle, cytochrome c and cytokine data detection. The level of significance was displayed on the plots as follows: $p<0.05\left(^{*}\right)$, $p<0.01(* *), p<0.001(* * *)$.

\section{Results}

\subsection{Examinations on Cultured Cells}

\subsubsection{CAP Reduced Viability in Normal and Tumour Cells}

CAP expels reactive species which are known to confer cytotoxic effects in eukaryotic cells in a concentration dependent manner. HaCaT keratinocytes and HNO97 cells were exposed to plasma-treated medium and their metabolic activity was reduced in a treatment time-dependent manner (Figure 2A). In order to compare both cell lines an $\mathrm{IC}_{50}$ value was calculated by sigmoid regression of relative resorufin fluorescence as a function of treatment time. The viability after incubation in CAP treated medium between both cell lines revealed very similar $\mathrm{IC}_{50}$ values; that is, $31 \mathrm{~s}$ for HaCaT keratinocytes and $36 \mathrm{~s}$ for HNO97 cells (Figure 2A). This suggests a comparable sensitivity towards plasma-induced redox stress for these two cell types of epidermal origin.

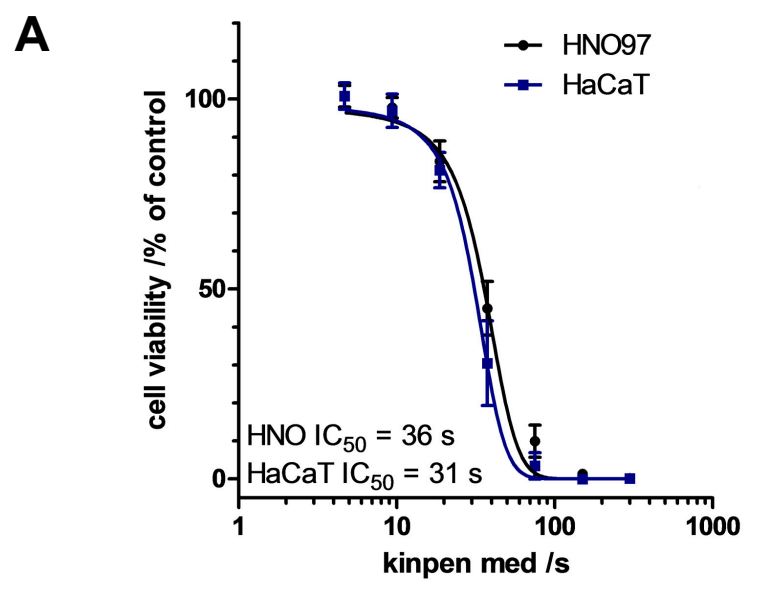

Figure 2. Cont. 
B

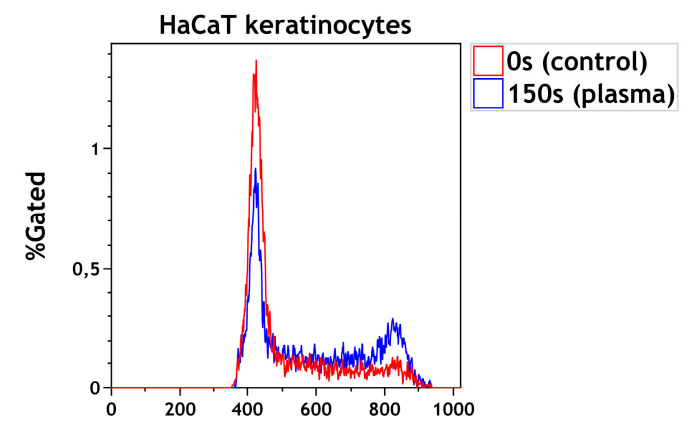

D

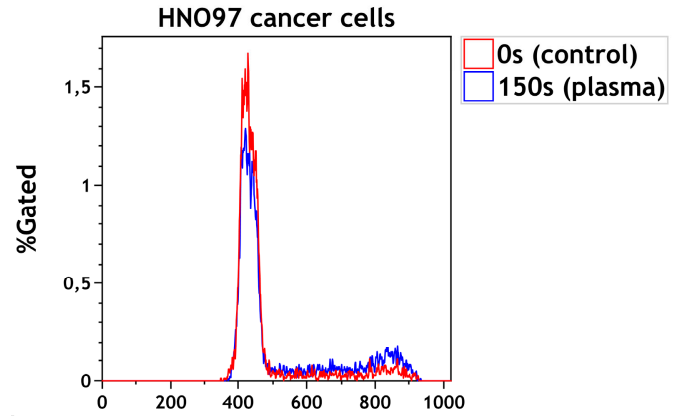

C

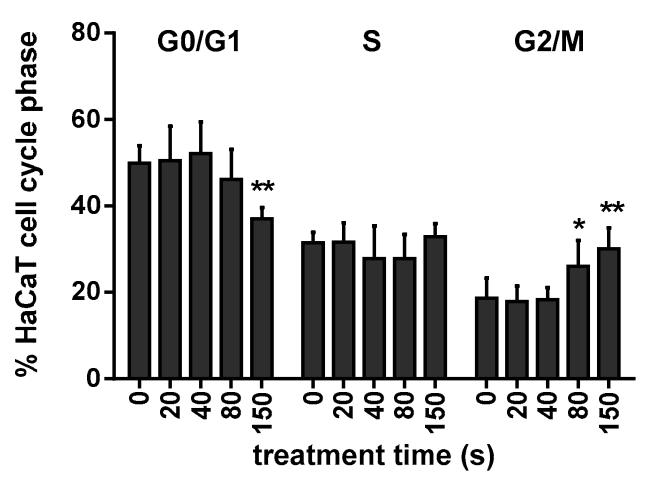

$\mathbf{E}$

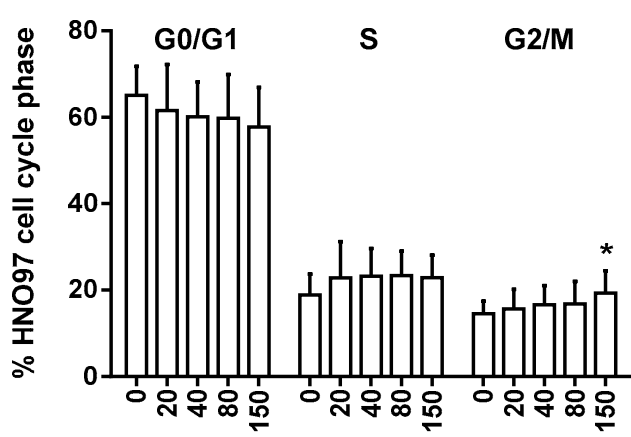

treatment time (s)

Figure 2. Comparison of the viability of HaCaT keratinocytes (blue line) and HNO97 (black line) in response to cold atmospheric pressure plasma (CAP) treated cell culture medium. (A). Cell viability is reduced after CAP treatment in both cell lines similarly. Formation of resorufin is plotted as a function of treatment time (log scale). Both curves summarize two individual experiments with 12 single measurements. $50 \%$ of viable cells $\left(\mathrm{IC}_{50}\right)$ are reached after $\mathrm{CAP}$ treatment for $31 \mathrm{~s}$ and $36 \mathrm{~s}$, respectively. Cell cycle analyses revealed a G2/M-arrest in HaCaT keratinocytes and HNO97 cancer cells by CAP treated cell culture medium. Representative histograms for control (red line) and $150 \mathrm{~s}$ treatment time (blue line) are displayed for HaCaT keratinocytes (B) and for HNO97 cancer cells (D). Both, HaCaT keratinocytes and HNO97 cells responded by a G2/M arrest with increasing CAP exposure time, most pronounced at $80 \mathrm{~s}$ and $150 \mathrm{~s}(\mathbf{C}$ and $\mathbf{E})$.

\subsubsection{Cell Cycle Arrest after CAP Treatment in HaCaT Keratinocytes and in HNO97 Cells}

The distribution of DAPI-stained cells was analysed according to the histogram plot of DNA content against cell numbers of both cell lines (representative examples are shown in Figure 2B,D. In HaCaT keratinocytes, CAP treated medium (80 s and $150 \mathrm{~s}$ ) caused a significantly elevated level of cells in the G2/M phase concomitant with a decrease in the proportion of cells in G0/G1 (Figure 2C). Of untreated cells $49 \%$ were in G0/G1 phase while this portion decreased significantly to $37 \%$ after $150 \mathrm{~s}$ CAP treatment. At the same time, cells in the G2/M phase increased from $18.6 \%$ to $30 \%$ for $150 \mathrm{~s}$ of CAP exposure. The impact of CAP treated medium on HNO97 cell cycle progression was less pronounced and revealed a decrease from $65 \%$ to $57.7 \%$ in the G0/G1 phase and a significant increase of $14.5 \%$ to $19.3 \%$ in the G2/M phase (Figure $2 \mathrm{E}$ ).

\subsubsection{CAP Exposure Activated Caspase in HNO97 Cancer Cells and HaCaT Keratinocytes}

Both cell lines, normal and head and neck squamous cell carcinoma cells, significantly activated caspase 3/7 when incubated in CAP treated medium. (Figure 3). A treatment time dependent activation of caspase 3/7 was present after CAP exposure in both cell types. Hence, significant activation of 
caspase 3/7 levels occurred after the longest treatment times of $80 \mathrm{~s}$ and $150 \mathrm{~s}$ (Figure 3). This result indicates a non-selective induction of apoptotic events in both cell lines.

\section{$6 \mathrm{~h}$}

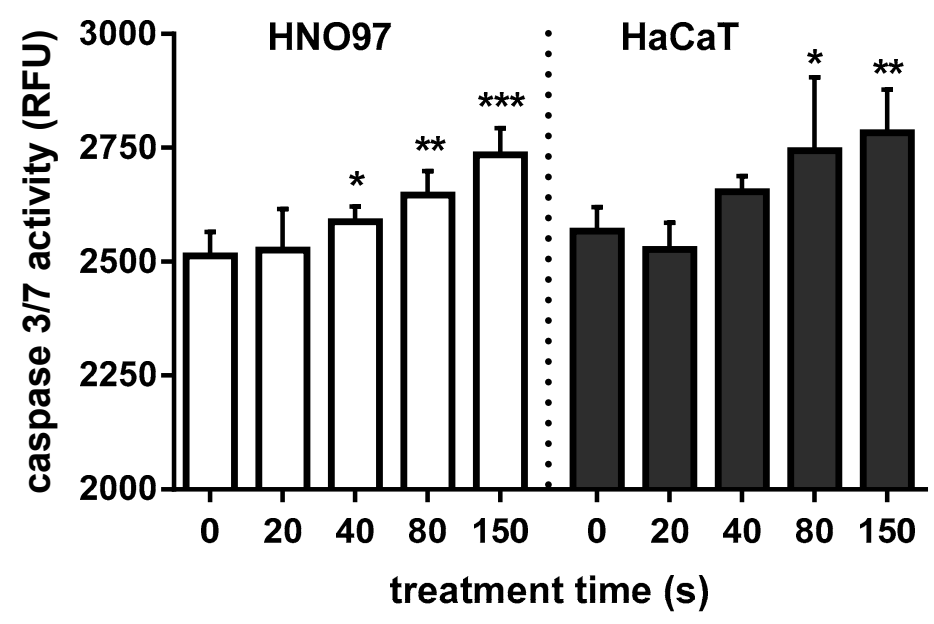

Figure 3. Activation of caspase $3 / 7$ by CAP treated cell culture medium in HaCaT keratinocytes and HNO97 cells. CAP treatment took place for 0, 20, 40, 80 and $150 \mathrm{~s}$ and incubation followed for $6 \mathrm{~h}$. Activation is detected as relative fluorescent units (RFU). Each bar resulted of three individual measurements (mean $+\mathrm{SD}$ ).

\subsubsection{Motility of Malignant Cells Was Significantly Impaired by CAP Treatment}

Motility and migration were analysed in a 2D-setup following incubation with CAP-treated culture medium comparing non-malignant and head and neck squamous cell carcinoma cells. Into a confluent layer of cells, the scratch width was measured at start $(0 \mathrm{~h})$, after $12 \mathrm{~h}$ and $24 \mathrm{~h}$ following addition of CAP-treated culture medium. By comparison, untreated HNO97 cells moved significantly faster (Figure 4A) than untreated $\mathrm{HaCaT}$ keratinocytes (Figure 4B); gap closure within $24 \mathrm{~h}$ constituted $50 \%$ and $20 \%$, respectively (Figure $4 \mathrm{C}$ ). CAP treatment on HaCaT cells had no significant influence for the tested treatment time regimen (Figure 4C). However, in head and neck squamous cell carcinoma cells gap closure was significantly reduced from $50 \%$ in untreated cells to $20 \%$ after CAP treatment. In summary, CAP treatment caused a significant impairment in the motility behaviour of HNO97 while HaCaT keratinocytes remained nearly unaffected. 

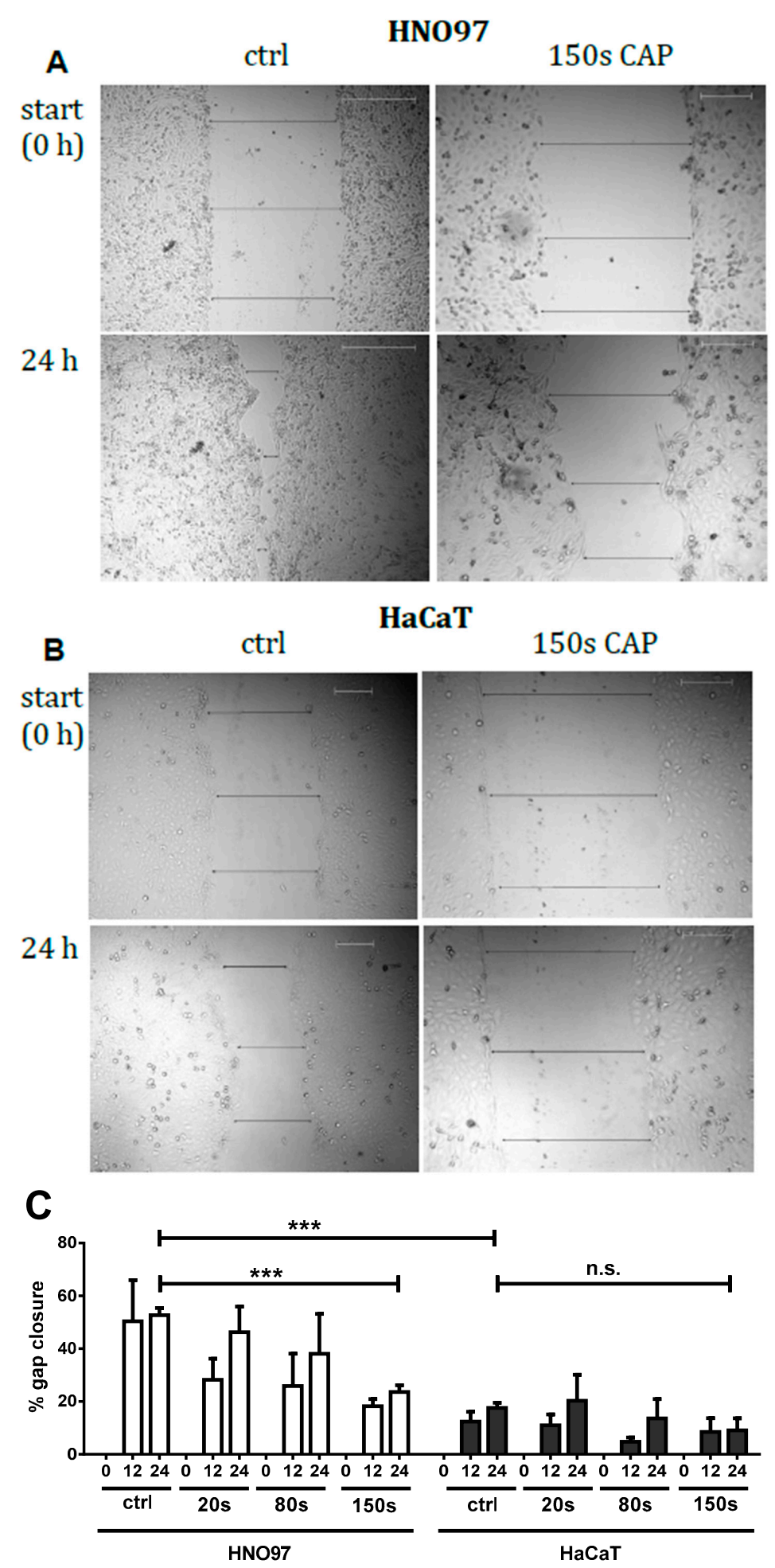

Figure 4. Cell motility was tested in HNO97 cancer cells and HaCaT keratinocytes in response to CAP treatment. Representative microscopic photographs of a scratch assay are depicted for (A) HNO97 and (B) HaCaT keratinocytes. Cell motility was evaluated as gap closure in $\%$ of the initial distance after 12 and $24 \mathrm{~h}$, respectively and displayed as bar graph (C) for both cell lines. HaCaT keratinocytes are significantly less motile compared to their malignant counterpart HNO97 (compare both ctrl). Addition of CAP treated medium reduced cell motility significantly in HNO97 (empty bars) while HaCaT keratinocytes are not affected (dark bars). The assay was performed at least in triplicates. Bars represent mean + SD. Magnification $\times 100$. 


\subsubsection{Total Protein Expression Modulated by CAP Treatment Reflect Changes in Cell Motility}

Several thousand proteins were detected in the investigated cell lines with a false discovery rate of $1 \%$ (5445 HaCaT/8258 HNO97), allowing a materially oversight of cell processes at sampling. Of these, $229 \mathrm{HaCaT}$ and $419 \mathrm{HNO} 97$ proteins are connected to cell migration (according to Uniprot gene ontology annotations) with 185 proteins detected in both cell types. Selected proteins are summarized in the Table 1 below.

Table 1. Expression of selected proteins in normal and malignant cells $3 \mathrm{~h}$ and $24 \mathrm{~h}$ after CAP treatment. Protein changes are indicated as: up to two-fold increased $\rightarrow \uparrow$; two-fold increased $\uparrow ; 5$ to 12-fold increased $\uparrow \uparrow$; two-fold decreased $\downarrow$; 5-12-fold decreased $\downarrow \downarrow ; ~ \leftrightarrow$ not changed.

\begin{tabular}{|c|c|c|c|c|}
\hline Protein Name & Uniprot ID & HaCaT & HNO97 & Function \\
\hline Ki67 & P46013 & $\Theta$ & $\rightarrow \uparrow$ & Proliferation \\
\hline NQO1 & P15559 & $\rightarrow \uparrow$ & $\leftrightarrow$ & $\begin{array}{l}\text { Nuclear factor erythroid 2-related factor } 2 \text { (NRF2) } \\
\text { related signalling }\end{array}$ \\
\hline TMX2 & Q9Y320 & $\uparrow$ & $\leftrightarrow$ & NRF2 related signalling \\
\hline GSTM3 & P21266 & $\uparrow$ & $\leftrightarrow$ & NRF2 related signalling \\
\hline PRDX1,2,4,6 & Q06830 & $\leftrightarrow$ & $\leftrightarrow$ & Redox regulation, elimination of peroxides \\
\hline SBNO2 & Q9Y2G9 & $\uparrow \uparrow$ & $\uparrow$ & Transcriptional co- regulation, interleukin signalling \\
\hline ILKAP & Q9H0C8 & $\uparrow \uparrow$ & $\leftrightarrow$ & Cell adhesion and growth factor signalling \\
\hline AAMP & Q13685 & $\rightarrow \uparrow$ & $\downarrow$ & Cell migration, angiogenesis \\
\hline ROCK2 & O75116 & $\rightarrow \uparrow$ & $\downarrow \downarrow$ & $\begin{array}{l}\text { Regulation of actin cytoskeleton, cell adhesion and } \\
\text { motility }\end{array}$ \\
\hline СТТВ2 & Q8WZ74 & $\uparrow \uparrow$ & $\rightarrow \uparrow$ & Cytoskeleton rearrangement, cell migration and motility \\
\hline CFA20 & Q9Y6A4 & $\uparrow \uparrow$ & $\leftrightarrow$ & Cell motility \\
\hline SRGP2 & O75044 & n.d. & $\uparrow$ & Cell migration inhibition, actin dynamics \\
\hline ELMO3 & Q96BJ8 & $\leftrightarrow$ & $\downarrow$ & Cell motility \\
\hline CASP8/10 & Q14790/Q92851 & $\leftrightarrow$ & $\uparrow$ & Pro-apoptotic caspases \\
\hline
\end{tabular}

\subsection{Examinations on Tissue Specimen}

Induction of apoptosis by CAP treatment was superior in tumour tissue compared with healthy mucosal tissue.

Following CAP triggered cytotoxicity and induction of early apoptotic events in cultured cells we next extended this view to biopsies of human non-malignant mucosa and squamous cell carcinoma of the head and neck area and investigated differences between these tissues after CAP treatment ( $3 \mathrm{~min}$ ). The number of apoptotic cells was evaluated in situ in the tumour tissue and in healthy mucosal tissue of the same patient. In healthy tissue, DNA fragmentation after CAP exposure indicative for apoptosis was marginal. Low numbers of TUNEL-positive cells were counted, namely $2.58 \%$ versus $0.79 \%$ at median in untreated samples and CAP treated tissue specimens, respectively (Figure 5). In contrast, the tissue samples of head and neck squamous cell carcinoma displayed a significantly elevated median number of apoptotic cells of 5.6\% compared to untreated tumour tissue (1.4\%). In this context, it is noteworthy to mention that individual responsiveness varies (Figure 5).

To strengthen the finding of induced apoptosis by CAP in tissue samples, the supernatant medium was analysed for cytochrome $\mathrm{c}$ and selected cytokines. As a marker for cell death, cytochrome $\mathrm{c}$ is released by mitochondria upon induction of apoptosis. Initially, the tumour tissue even without CAP treatment revealed a much higher amount of cytochrome $\mathrm{c}$ than the corresponding healthy tissue (1729 ng per mg protein versus $385 \mathrm{ng}$ per mg protein) (Figure 6). However, the CAP treatment triggered apoptotic pathways and the cytochrome c concentration raised significantly to as high as $5155 \mathrm{ng}$ per mg protein in the supernatant of the tumour tissue (three-fold increase). Strikingly this was not the case for the corresponding healthy tissue. Here the same CAP treatment regimen led to a mean cytochrome c content of 698 ng per mg protein (1,8-fold increase) (Figure 6). 


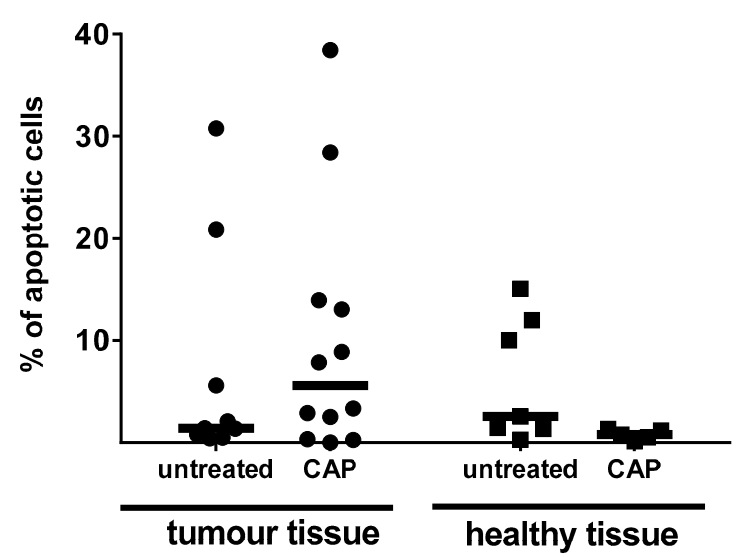

Figure 5. Induction of apoptotic cells by CAP application in tumour tissue in situ. TUNEL-positive cells were detected in several specimen of squamous cell carcinoma as well as in healthy tissue donated by the same patient. Results are displayed as scatter dot plot with a line at median. While healthy tissue revealed only very few TUNEL-positive cells after CAP exposure for $3 \mathrm{~min}$ the number increased in tumour tissue. Note the inter individual variance.
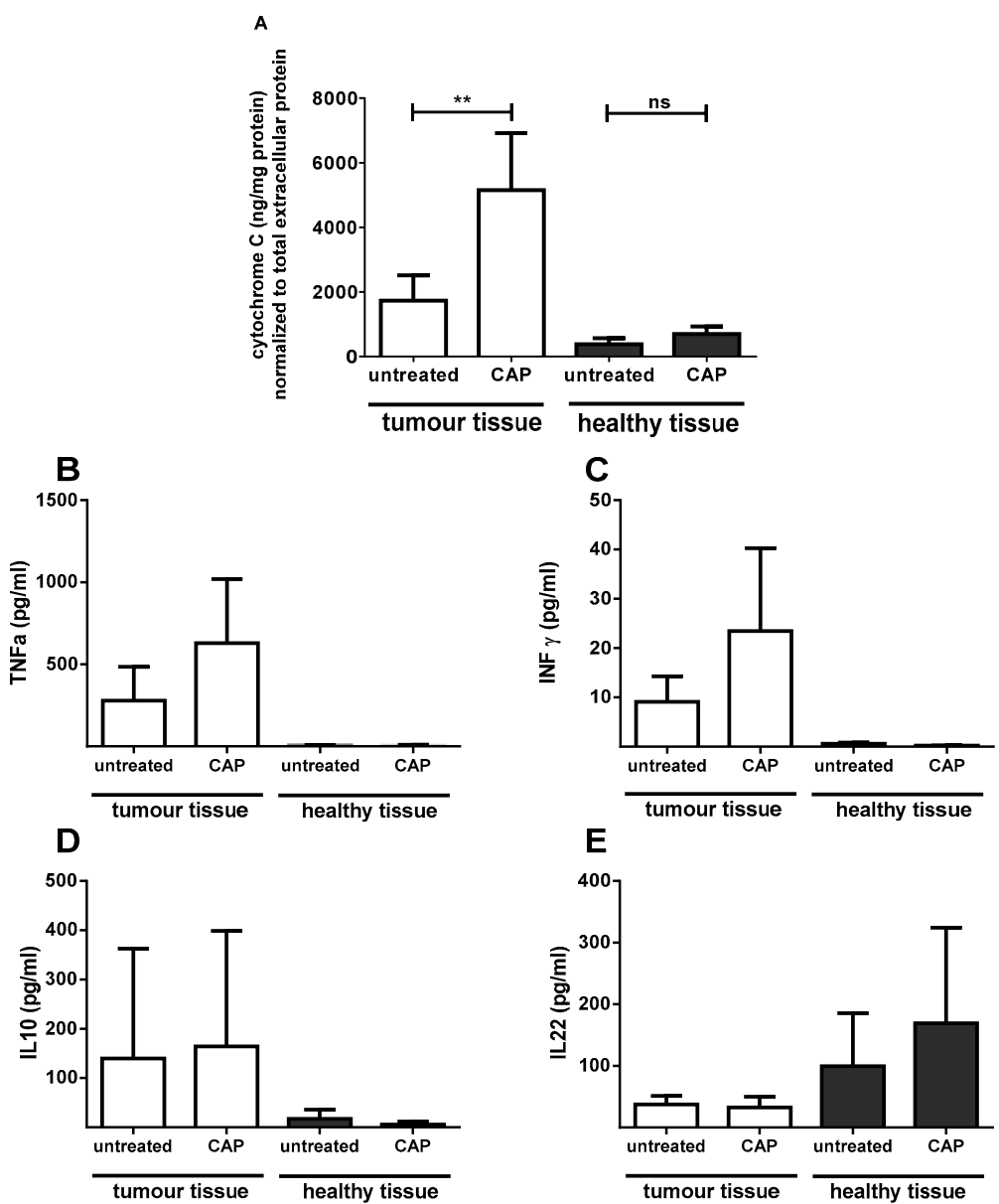

Figure 6. Detection of extracellular cytochrome c (A) and different cytokines (B-E) released by the tissue samples into the supernatant after CAP treatment. Secreted proteins were detected in the supernatant medium in which tissue specimen have been maintained for $24 \mathrm{~h}$ after CAP exposure. Higher extracellular cytochrome c levels were detected in tumour tissue compared to healthy mucosa of the same patient after CAP treatment $(n=9)$. The concentration of cytochrome $\mathrm{c}$ was normalized to total extracellular protein and bars represent mean $+\operatorname{SEM}$. TNF $\alpha, \operatorname{IFN} \gamma, \operatorname{IL10}$ and IL22 ( $\mathrm{n}=5$ ) were simultaneously detected by a bead based immunoassay and compared between tumour tissue and healthy tissue. Bars represent mean + SEM. 
Taken together, the results revealed that tissue of healthy and malignant origin differed significantly in their response to CAP treatment. Induction of apoptosis occurred predominantly in tumour tissue while in healthy tissue the impact of CAP was not significant. This finding inspired us to look for mediators like cytokines in conditioned medium in a preliminary test. Tumour necrosis factor $\alpha$ (TNF $\alpha)$, interferon $\gamma(\mathrm{IFN} \gamma)$, interleukin (IL) 10 and IL22 were detected and results are presented in Figure 6B-E. Due to small sample size and inter individual variances, only a tendency can be derived (Figure 6B-E). Strikingly higher concentrations of IL22 were released from healthy tissue while INF $\gamma, \mathrm{TNF} \alpha$ and IL10 were found predominantly in tumour tissue of the corresponding patient (Figure 6B,C,D). CAP treatment tends to increase the levels of TNF $\alpha$ and IFN $\gamma$ in tumour tissue but showed no effect in corresponding healthy tissue.

\section{Discussion}

The delivery of CAP-generated ROS and RNS through the liquid environment to cells changes the redox environment, which ultimately may induce cytotoxic effects [29,30]. With respect to cancer treatment, it is widely accepted that CAP-generated ROS and RNS are the main agents to induce cell death and apoptosis in cancer cells $[6,24,31]$. After CAP application an increasing number of apoptotic cancer cells positively correlate with an increased concentration of nitric oxide (NO), ROS and lipid peroxidation products [32]. Others demonstrated that CAP induces apoptosis via ROS and dysfunction of mitochondrial membranes [23]. In addition, autophagy has been discussed as another way of cell death after CAP exposure especially in primary cells [33]. This illustrates the great potential of CAP in the therapeutic concept of tumour treatment on the basis of ROS/RNS generation. In this context eliminating cancer cells by pharmacological ROS insults has also been developed independent of CAP technology [34]. The mode of action of some chemotherapeutic agents employs partly the production of ROS and therefore enhances their cytotoxic effectiveness (e.g., cisplatin or bleomycin) [35-38]. Even more so, a synergistic effect of gemcitabine and CAP in killing pancreatic tumour cells has been described recently [39].

Squamous cell carcinoma of the head and neck can grow in very close vicinity to vital structures (Figure 1), hence pose a surgical challenge for resection. Therefore, this study investigated CAP application as a potential adjuvant tool in the treatment of squamous cell carcinoma in this region. Unique advantages of the CAP application are the accessibility of localized areas and upon this time no known side effects [5,9].

In our study the certified medical device kINPen MED was employed to generate CAP. The therapeutic concept of the kINPen is based on the generation of ROS and RNS (RONS) [40]. Recently, a beneficial effect of this argon plasma jet treatment on head and neck cancer was documented in a retrospective clinical follow-up study by Metelmann and colleagues [41]. Several repeated cycles of CAP application for only one minute lead to partial remission of the tumour in $36 \%$ of the cases but prominent histological alterations were absent. Herein ex vivo treated tissue biopsies revealed an increased number of apoptotic cells within the tissue and elevated levels of cytochrome $\mathrm{c}$ in the extracellular liquid, pointing to profound apoptotic cell damage. This is in good agreement with clinical findings in head and neck squamous cell carcinoma patients [9]. In our approach, the distribution of TUNEL-positive cells was rather randomly dispersed throughout the tissue sections (data not shown), pointing to a non-cell-cell-contact-based mechanism. Contrary, results from Partecke et al. showed more dying cells in the outermost layers of treated pancreatic carcinoma tissue concomitant with reduced proliferation [42]. The therapeutic application of CAP in cancer treatment requires certain selectivity towards malignant cells. In our experimental setup we could show stronger induction of apoptosis in tumour tissue in situ compared to healthy tissue. In order to follow events in a 2D cell culture setup, two corresponding cell lines were selected, normal HaCaT keratinocytes and HNO97 derived from a human squamous cell carcinoma of the head and neck. However, the cell lines used revealed very little difference with respect to induction of apoptotic events after CAP exposure. Hence, the selectivity was not established in these in vitro tests. This may be due to the simple homogeneous 
cell population. Further the sensitivity towards CAP varies among HNSCC and non-malignant cell lines and the underlying molecular composition should be considered for future examinations. By contrast, others found that CAP selectively impairs some cell lines of head and neck squamous cell carcinoma also through non-apoptotic pathways [24,43]. The idea of CAP selectivity for cancer cells has been debated recently and a selective CAP effect on tumour cells has been ascribed to divergent metabolic features, anti-oxidative capacity or erroneous signalling processes [24,25,44,45].

In addition to cytotoxic events, the cells motility also was investigated. To preclude a risk, HaCaT and HNO97 cells were tested for their ability to move into a scratch. In this model, CAP treatment significantly decreased cell motility in squamous cell carcinoma cells only but not in non-malignant keratinocytes. Protein expression profiles support this finding by identifying reduced expression of several proteins related to cytoskeleton rearrangement, motility and cell migration. Cell motility as well as cell-cell-adhesion are both closely related to the expression of E-cadherin among other adhesion molecules. Previous research showed that the expression of E-cadherin negatively correlates with the progression of oral squamous cell carcinoma and dedifferentiation [46]. Interestingly, elevated E-cadherin and EGFR expression level were earlier detected after CAP treatment in HaCaT keratinocytes [47] but not in HNO97 cells.

Notably, the expression of angio-associated migratory cell protein (AAMP) also correlated with the migratory activity in several cell types, including smooth muscle cells and endothelial cells [48]. The expression of AAMP was reduced after CAP treatment in HNO97, whereas its expression slightly increased in $\mathrm{HaCaT}$ cells depending on the treatment intensity and time point [49]. We also observed that AAMP was secreted into the extracellular compartment and acts upon neighbouring cells, potentially contributing to remote effects of CAP.

Interestingly, for non-malignant murine fibroblasts a change in integrin expression concomitant with reduced motility after CAP exposure was reported earlier [50]. Moreover, we found that also SK-MEL-147 human melanoma cells displayed significantly decreased cell motility when subjected to CAP-treated medium [51]. This effect was correlated with alterations in the cytoskeleton, such as actin fibre rearrangement, and hence agrees well with alterations in non-melanoma skin cancer cells.

Regarding redox signalling events our results are in accordance with Weiss et al., who described unaltered protein levels of peroxiredoxin 1 and 2 after CAP exposure [52].

Moreover, our results illustrate the high complexity and heterogeneity of tumour tissue consisting of extracellular matrix, immune cells and epithelial cells. This led us to investigate extracellular cytokines after CAP exposure that function as mediators. Our results merely detected four immunomodulatory cytokines with different concentrations in healthy versus tumour tissue. Especially IL10 has been detected at higher levels in squamous cell carcinoma by others [53] and is in accordance with our finding. Considering the central role of INF $\gamma$ in keratinocyte apoptosis and TNF $\alpha$ 's potential to increase this effect, it is noticeable that our approach revealed an increased concentration of INF $\gamma$ and TNF $\alpha$ after CAP treatment in tumour tissue [54]. This is in good agreement with detected elevated cytochrome c levels after CAP treatment. Effects mediated by second messenger like the AAMP protein or the interleukins and cellular signalling in response to CAP application remain largely elusive but require more attention in future approaches.

Intriguingly variations between HaCaT keratinocytes and HNO97 squamous cell carcinoma cells were rather minor in our 2D cell culture approach whereas patient derived tissue revealed very differential responses towards CAP treatment. This finding highlights the need to employ clinically relevant model systems for further preclinical investigations of CAP.

\section{Conclusions}

- Controlled application of CAP may provide a means to kill malignant cells.

- CAP application may be a promising adjuvant treatment option to eliminate minimal residual cancer cells after radical surgery of carcinoma of the head and neck area. 
- Investigations towards the underlying mechanism remain to be addressed under consideration of accompanying cell types.

Author Contributions: Conceptualization, analysis, investigation: S.H., C.S., K.W., A.S., S.B.; writing-original draft preparation: S.H., C.S., A.S., S.B.; writing-review and editing, H.-R.M, T.v.W.

Funding: S.B. and K.W. received funding by the Federal Ministry of Education and Research (BMBF), grant no. 03Z22DN11 and 03Z22DN12.

Acknowledgments: The authors thank Liane Kantz for her excellent technical assistance.

Conflicts of Interest: The authors declare no conflict of interest.

Declarations: Ethics approval and consent to participate: Tissue sampling for ex vivo CAP treatment and investigation was approved by the ethics committee of the University Medicine Greifswald (approval number: BB61/11b). Informed consent was obtained from each patient prior to examinations.

\section{References}

1. Ferlay, J.; Steliarova-Foucher, E.; Lortet-Tieulent, J.; Rosso, S.; Coebergh, J.W.W.; Comber, H.; Forman, D.; Bray, F. Cancer incidence and mortality patterns in Europe: Estimates for 40 countries in 2012. Eur. J. Cancer 2013, 49, 1374-1403. [CrossRef]

2. Von Woedtke, T.; Reuter, S.; Masur, K.; Weltmann, K.D. Plasmas for medicine. Phys. Rep. 2013, 530, 291-320. [CrossRef]

3. Weltmann, K.D.; Kindel, E.; Brandenburg, R.; Meyer, C.; Bussiahn, R.; Wilke, C.; von Woedtke, T. Atmospheric Pressure Plasma Jet for Medical Therapy: Plasma Parameters and Risk Estimation. Contrib. Plasma Phys. 2009, 49, 631-640. [CrossRef]

4. Isbary, G.; Shimizu, T.; Li, Y.F.; Stolz, W.; Thomas, H.M.; Morfill, G.E.; Zimmermann, J.L. Cold atmospheric plasma devices for medical issues. Expert Rev. Med. Dev. 2013, 10, 367-377. [CrossRef]

5. Bekeschus, S.; Schmidt, A.; Weltmann, K.-D.; von Woedtke, T. The plasma jet kINPen-A powerful tool for wound healing. Clin. Plasma Med. 2016, 4, 19-28. [CrossRef]

6. Vandamme, M.; Robert, E.; Lerondel, S.; Sarron, V.; Ries, D.; Dozias, S.; Sobilo, J.; Gosset, D.; Kieda, C.; Legrain, B.; et al. ROS implication in a new antitumor strategy based on non-thermal plasma. Int. J. Cancer 2012, 130, 2185-2194. [CrossRef] [PubMed]

7. Keidar, M.; Shashurin, A.; Volotskova, O.; Ann Stepp, M.; Srinivasan, P.; Sandler, A.; Trink, B. Cold atmospheric plasma in cancer therapy. Phys. Plasmas 2013, 20, 057101. [CrossRef]

8. Schlegel, J.; Köritzer, J.; Boxhammer, V. Plasma in cancer treatment. Clin. Plasma Med. 2013, 1, 2-7. [CrossRef]

9. Schuster, M.; Seebauer, C.; Rutkowski, R.; Hauschild, A.; Podmelle, F.; Metelmann, C.; Metelmann, B.; von Woedtke, T.; Hasse, S.; Weltmann, K.D.; et al. Visible tumor surface response to physical plasma and apoptotic cell kill in head and neck cancer. J. Cranio-Maxillo-Facial Surg. 2016, 44, 1445-1452. [CrossRef]

10. Fridman, G.; Friedman, G.; Gutsol, A.; Shekhter, A.B.; Vasilets, V.N.; Fridman, A. Applied Plasma Medicine. Plasma Process. Polym. 2008, 5, 503-533. [CrossRef]

11. Heinlin, J.; Morfill, G.; Landthaler, M.; Stolz, W.; Isbary, G.; Zimmermann, J.L.; Shimizu, T.; Karrer, S. Plasma medicine: Possible applications in dermatology. J. Dtsch. Dermatol. Ges. 2010, 8, 968-976. [CrossRef] [PubMed]

12. Heinlin, J.; Schiffner-Rohe, J.; Schiffner, R.; Einsele-Kramer, B.; Landthaler, M.; Klein, A.; Zeman, F.; Stolz, W.; Karrer, S. A first prospective randomized controlled trial on the efficacy and safety of synchronous balneophototherapy vs. narrow-band UVB monotherapy for atopic dermatitis. J. Eur. Acad. Dermatol. Venereol. JEADV 2011, 25, 765-773. [CrossRef]

13. Isbary, G.; Heinlin, J.; Shimizu, T.; Zimmermann, J.L.; Morfill, G.; Schmidt, H.U.; Monetti, R.; Steffes, B.; Bunk, W.; Li, Y.; et al. Successful and safe use of 2 min cold atmospheric argon plasma in chronic wounds: Results of a randomized controlled trial. Br. J. Dermatol. 2012, 167, 404-410. [CrossRef]

14. Isbary, G.; Morfill, G.; Schmidt, H.U.; Georgi, M.; Ramrath, K.; Heinlin, J.; Karrer, S.; Landthaler, M.; Shimizu, T.; Steffes, B.; et al. A first prospective randomized controlled trial to decrease bacterial load using cold atmospheric argon plasma on chronic wounds in patients. Br. J. Dermatol. 2010, 163, 78-82. [CrossRef] [PubMed] 
15. Metelmann, H.R.; Woedtke, T.; Bussiahn, R.; Weltmann, K.D.; Rieck, M.; Khalili, R.; Podmelle, F.; Waite, P. Experimental Recovery of $\mathrm{CO}_{2}$-Laser skin lesions by plasma stimulation. Am. J. Cosm. Surg. 2012, 29, 52-56. [CrossRef]

16. Metelmann, H.-R.; Vu, T.T.; Do, H.T.; Le, T.N.B.; Hoang, T.H.A.; Phi, T.T.T.; Luong, T.M.L.; Doan, V.T.; Nguyen, T.T.H.; Nguyen, T.H.M.; et al. Scar formation of laser skin lesions after cold atmospheric pressure plasma (CAP) treatment: A clinical long term observation. Clin. Plasma Med. 2013, 1, 30-35. [CrossRef]

17. Brehmer, F.; Haenssle, H.A.; Daeschlein, G.; Ahmed, R.; Pfeiffer, S.; Gorlitz, A.; Simon, D.; Schon, M.P.; Wandke, D.; Emmert, S. Alleviation of chronic venous leg ulcers with a hand-held dielectric barrier discharge plasma generator (PlasmaDerm VU-2010): Results of a monocentric, two-armed, open, prospective, randomized and controlled trial (NCT01415622). J. Eur. Acad. Dermatol. Venereol. JEADV 2015, 29, 148-155. [CrossRef] [PubMed]

18. Nasruddin; Nakajima, Y.; Mukai, K.; Rahayu, H.S.E.; Nur, M.; Ishijima, T.; Enomoto, H.; Uesugi, Y.; Sugama, J.; Nakatani, T. Cold plasma on full-thickness cutaneous wound accelerates healing through promoting inflammation, re-epithelialization and wound contraction. Clin. Plasma Med. 2014, 2, $28-35$. [CrossRef]

19. Daeschlein, G.; Scholz, S.; Ahmed, R.; von Woedtke, T.; Haase, H.; Niggemeier, M.; Kindel, E.; Brandenburg, R.; Weltmann, K.D.; Juenger, M. Skin decontamination by low-temperature atmospheric pressure plasma jet and dielectric barrier discharge plasma. J. Hosp. Infect. 2012, 81, 177-183. [CrossRef]

20. Daeschlein, G.; Scholz, S.; Arnold, A.; von Podewils, S.; Haase, H.; Emmert, S.; von Woedtke, T.; Weltmann, K.-D.; Jünger, M. In Vitro Susceptibility of Important Skin and Wound Pathogens Against Low Temperature Atmospheric Pressure Plasma Jet (APPJ) and Dielectric Barrier Discharge Plasma (DBD). Plasma Process. Polym. 2012, 9, 380-389. [CrossRef]

21. Hasse, S.; Duong Tran, T.; Hahn, O.; Kindler, S.; Metelmann, H.R.; von Woedtke, T.; Masur, K. Induction of proliferation of basal epidermal keratinocytes by cold atmospheric-pressure plasma. Clin. Exp. Dermatol. 2016, 41, 202-209. [CrossRef]

22. Sensenig, R.; Kalghatgi, S.; Cerchar, E.; Fridman, G.; Shereshevsky, A.; Torabi, B.; Arjunan, K.P.; Podolsky, E.; Fridman, A.; Friedman, G.; et al. Non-thermal plasma induces apoptosis in melanoma cells via production of intracellular reactive oxygen species. Ann. Biomed. Eng. 2011, 39, 674-687. [CrossRef] [PubMed]

23. Ahn, H.J.; Kim, K.I.; Hoan, N.N.; Kim, C.H.; Moon, E.; Choi, K.S.; Yang, S.S.; Lee, J.S. Targeting Cancer Cells with Reactive Oxygen and Nitrogen Species Generated by Atmospheric-Pressure Air Plasma. PLoS ONE 2014, 9, 1. [CrossRef]

24. Guerrero-Preston, R.; Ogawa, T.; Uemura, M.; Shumulinsky, G.; Valle, B.L.; Pirini, F.; Ravi, R.; Sidransky, D.; Keidar, M.; Trink, B. Cold atmospheric plasma treatment selectively targets head and neck squamous cell carcinoma cells. Int. J. Mol. Med. 2014, 34, 941-946. [CrossRef] [PubMed]

25. Keidar, M.; Walk, R.; Shashurin, A.; Srinivasan, P.; Sandler, A.; Dasgupta, S.; Ravi, R.; Guerrero-Preston, R.; Trink, B. Cold plasma selectivity and the possibility of a paradigm shift in cancer therapy. Br. J. Cancer 2011, 105, 1295-1301. [CrossRef]

26. Lu, Z.; Hasse, S.; Bodo, E.; Rose, C.; Funk, W.; Paus, R. Towards the development of a simplified long-term organ culture method for human scalp skin and its appendages under serum-free conditions. Exp. Dermatol. 2007, 16, 37-44. [CrossRef] [PubMed]

27. Hasse, S.; Hahn, O.; Kindler, S.; von Woedtke, T.; Metelmann, H.-R.; Masur, K. Atmospheric pressure plasma jet application on human oral mucosa modulates tissue regeneration. Plasma Med. 2014, 4, 431-438. [CrossRef]

28. Wende, K.; Reuter, S.; von Woedtke, T.; Weltmann, K.-D.; Masur, K. Redox-Based Assay for Assessment of Biological Impact of Plasma Treatment. Plasma Process. Polym. 2014, 11, 655-663. [CrossRef]

29. Graves, D.B. The emerging role of reactive oxygen and nitrogen species in redox biology and some implications for plasma applications to medicine and biology. J. Phys. D Appl. Phys. 2012, 45, 263001. [CrossRef]

30. Graves, D.B. Oxy-nitroso shielding burst model of cold atmospheric plasma therapeutics. Clin. Plasma Med. 2014, 2, 38-49. [CrossRef]

31. Graves, D.B. Reactive Species from Cold Atmospheric Plasma: Implications for Cancer Therapy. Plasma Process. Polym. 2014, 11, 1120-1127. [CrossRef]

32. Yan, K.; Kanazawa, S.; Ohkubo, T.; Nomoto, Y. Oxidation and reduction processes during $\mathrm{NO}(\mathrm{x})$ removal with corona-induced nonthermal plasma. Plasma Chem. Plasma P 1999, 19, 421-443. [CrossRef] 
33. Hirst, A.M.; Simms, M.S.; Mann, V.M.; Maitland, N.J.; O'Connell, D.; Frame, F.M. Low-temperature plasma treatment induces DNA damage leading to necrotic cell death in primary prostate epithelial cells. Br. J. Cancer 2015, 112, 1536-1545. [CrossRef] [PubMed]

34. Trachootham, D.; Alexandre, J.; Huang, P. Targeting cancer cells by ROS-mediated mechanisms: A radical therapeutic approach? Nat. Rev. Drug. Discov. 2009, 8, 579-591. [CrossRef] [PubMed]

35. Engel, R.H.; Evens, A.M. Oxidative stress and apoptosis: A new treatment paradigm in cancer. Front. Biosci. 2006, 11, 300-312. [CrossRef]

36. Gorrini, C.; Harris, I.S.; Mak, T.W. Modulation of oxidative stress as an anticancer strategy. Nat. Rev. Drug. Discov. 2013, 12, 931-947. [CrossRef]

37. Hay, J.; Shahzeidi, S.; Laurent, G. Mechanisms of bleomycin-induced lung damage. Arch. Toxicol. 1991, 65, 81-94. [CrossRef] [PubMed]

38. Marullo, R.; Werner, E.; Degtyareva, N.; Moore, B.; Altavilla, G.; Ramalingam, S.S.; Doetsch, P.W. Cisplatin Induces a Mitochondrial-ROS Response That Contributes to Cytotoxicity Depending on Mitochondrial Redox Status and Bioenergetic Functions. PLoS ONE 2013, 8, 11. [CrossRef] [PubMed]

39. Masur, K.; von Behr, M.; Bekeschus, S.; Weltmann, K.-D.; Hackbarth, C.; Heidecke, C.-D.; von Bernstorff, W.; von Woedtke, T.; Partecke, L.I. Synergistic Inhibition of Tumor Cell Proliferation by Cold Plasma and Gemcitabine. Plasma Process. Polym. 2015, 12, 1377-1382. [CrossRef]

40. Reuter, S.; Tresp, H.; Wende, K.; Hammer, M.U.; Winter, J.; Masur, K.; Schmidt-Bleker, A.; Weltmann, K.D. From RONS to ROS: Tailoring Plasma Jet Treatment of Skin Cells. IEEE Trans. Plasma Sci. 2012, 40, $2986-2993$. [CrossRef]

41. Metelmann, H.-R.; Nedrelow, D.S.; Seebauer, C.; Schuster, M.; von Woedtke, T.; Weltmann, K.-D.; Kindler, S.; Metelmann, P.H.; Finkelstein, S.E.; von Hoff, D.D.; et al. Head and neck cancer treatment and physical plasma. Clin. Plasma Med. 2015, 3, 17-23. [CrossRef]

42. Partecke, L.I.; Evert, K.; Haugk, J.; Doring, F.; Normann, L.; Diedrich, S.; Weiss, F.U.; Evert, M.; Hubner, N.O.; Gunther, C.; et al. Tissue Tolerable Plasma (TTP) induces apoptosis in pancreatic cancer cells in vitro and in vivo. BMC Cancer 2012, 12, 473. [CrossRef]

43. Welz, C.; Emmert, S.; Canis, M.; Becker, S.; Baumeister, P.; Shimizu, T.; Morfill, G.E.; Harreus, U.; Zimmermann, J.L. Cold Atmospheric Plasma: A Promising Complementary Therapy for Squamous Head and Neck Cancer. PLoS ONE 2015, 10, e0141827. [CrossRef] [PubMed]

44. Ma, Y.H.; Ha, C.S.; Hwang, S.W.; Lee, H.J.; Kim, G.C.; Lee, K.W.; Song, K. Non-Thermal Atmospheric Pressure Plasma Preferentially Induces Apoptosis in p53-Mutated Cancer Cells by Activating ROS Stress-Response Pathways. PLoS ONE 2014, 9, 4. [CrossRef] [PubMed]

45. Wang, M.; Holmes, B.; Cheng, X.; Zhu, W.; Keidar, M.; Zhang, L.G. Cold atmospheric plasma for selectively ablating metastatic breast cancer cells. PLoS ONE 2013, 8, e73741. [CrossRef] [PubMed]

46. Kaur, G.; Carnelio, S.; Rao, N.; Rao, L. Expression of E-cadherin in primary oral squamous cell carcinoma and metastatic lymph nodes: An immunohistochemical study. Ind. J. Dent. Res. 2009, 20, 71-76.

47. Haertel, B.; Wende, K.; von Woedtke, T.; Weltmann, K.D.; Lindequist, U. Non-thermal atmospheric-pressure plasma can influence cell adhesion molecules on HaCaT-keratinocytes. Exp. Dermatol. 2011, 20, $282-284$. [CrossRef] [PubMed]

48. Beckner, M.E.; Jagannathan, S.; Peterson, V.A. Extracellular angio-associated migratory cell protein plays a positive role in angiogenesis and is regulated by astrocytes in coculture. Microvasc. Res. 2002, 63, $259-269$. [CrossRef]

49. Schmidt, A.; Bekeschus, S.; Wende, K.; Vollmar, B.; von Woedtke, T. A cold plasma jet accelerates wound healing in a murine model of full-thickness skin wounds. Exp. Dermatol. 2017, 26, 156-162. [CrossRef]

50. Shashurin, A.; Stepp, M.A.; Hawley, T.S.; Pal-Ghosh, S.; Brieda, L.; Bronnikov, S.; Jurjus, R.A.; Keidar, M. Influence of Cold Plasma Atmospheric Jet on Surface Integrin Expression of Living Cells. Plasma Process. Polym. 2010, 7, 294-300. [CrossRef]

51. Schmidt, A.; Bekeschus, S.; von Woedtke, T.; Hasse, S. Cell migration and adhesion of a human melanoma cell line is decreased by cold plasma treatment. Clin. Plasma Med. 2015, 3, 24-31. [CrossRef]

52. Weiss, M.; Gumbel, D.; Hanschmann, E.M.; Mandelkow, R.; Gelbrich, N.; Zimmermann, U.; Walther, R.; Ekkernkamp, A.; Sckell, A.; Kramer, A.; et al. Cold Atmospheric Plasma Treatment Induces Anti-Proliferative Effects in Prostate Cancer Cells by Redox and Apoptotic Signaling Pathways. PLoS ONE 2015, 10, e0130350. [CrossRef] [PubMed] 
53. Kim, J.; Modlin, R.L.; Moy, R.L.; Dubinett, S.M.; Mchugh, T.; Nickoloff, B.J.; Uyemura, K. Il-10 Production in Cutaneous Basal and Squamous-Cell Carcinomas-A Mechanism for Evading the Local T-Cell Immune-Response. J. Immunol. 1995, 155, 2240-2247.

54. Konur, A.; Schulz, U.; Eissner, G.; Andreesen, R.; Holler, E. Interferon (IFN)- $\gamma$ is a main mediator of keratinocyte (HaCaT) apoptosis and contributes to autocrine IFN- $\gamma$ and tumour necrosis factor- $\alpha$ production. Br. J. Dermatol. 2005, 152, 1134-1142. [CrossRef] [PubMed]

(C) 2019 by the authors. Licensee MDPI, Basel, Switzerland. This article is an open access article distributed under the terms and conditions of the Creative Commons Attribution (CC BY) license (http://creativecommons.org/licenses/by/4.0/). 